\title{
TIESLIETU PADOMES LĒMUMU EFEKTIVITĀTE
}

\section{EFFECTIVENESS OF JUDICIAL COUNCIL'S DECISIONS}

\author{
Solvita Harbaceviča, LL.M. \\ Latvijas Universitātes Juridiskās fakultātes \\ Tiesību teorijas un vēstures katedras doktorante
}

\begin{abstract}
Summary
The question of effectiveness of Judicial Council's decisions becomes topical in period of voiced disagreements among state powers. European type of Judicial Councils is designed to give strong representation to judiciary's voice, however for any state power to be fully effective they need to conduct a dialogue and cooperate among themselves. The article looks at several recent examples of overlapping competencies, paying particular attention to the newly and controversially established Economic Affairs Court. The status of Judicial Council's decisions in Latvian legal system is addressed, as well.
\end{abstract}

Atslēgvārdi: Tieslietu padomes Eiropas modelis, tiesu sistēmas viedokḷa formulēšana, dialogs valsts varu starpā, Ekonomisko lietu tiesa, Tieslietu padomes lēmumu statuss.

Keywords: European model of Judicial Councils, formulating judiciary's opinions, dialogue among state powers, Economic Affairs Court, status of Judicial Council's decisions.

\section{Ievads}

Jautājums par Tieslietu padomes lēmumu efektivitāti īpaši aktualizējas brīdī, kad kḷusst publiski redzamas viedokḷu atšşirīibas vai pat konflikti valsts varu starpā būtiskos tieslietu sistēmas stratēógiskajos jautājumos.

Analizējot šo tēmu, primāri jāatceras, ka aplūkojamās institūcijas - Tieslietu padomes - pastāvēšanas un darbības jēga nav pašpietiekamībā, bet gan tās spējā dot pienesumu triju valsts varu līdzsvarošanā un savstarpējā kontrolē.

Arī tiesu varas neatkarība un efektivitāte nav pašmērḳis, bet gan absolūti nepieciešams demokrātiskas valsts elements. Tiesu sistēma ir viens no trijiem vienlīdz svarīgajiem modernas demokrātiskas valsts pīlāriem. Demokrātiskā valstīi, kurā valda likuma vara, neviena no trijām varām nedarbojas pati savās interesēs, bet tautas interesēs kopumā. Turklāt visām varām jādarbojas, pamatojoties uz likumu un tā noteiktajās robežās. ${ }^{1}$ Ir būtiski nodrošināt, ka lieta tiesā tiek izlemta, balstoties uz spēkā esošajām tiesību normām (arī tiesību principiem), un ka to

${ }^{1}$ Consultative Council of European Judges (CCJE), Opinion No.18 (2015) "The position of the judiciary and its relation with the other powers of state in a modern democracy" CCJE(2015)4. Pieejams: https:// rm.coe.int/16807481al (tālāk atsaucēs - viedoklis Nr. 18), 6. punkts [aplūkots 17.03.2021.]. 
lēmis neatkarīgs, neietekmējams tiesnesis vai tiesas sastāvs. Šīm garantijām jābūt reālām, nevis iluzorām.

Tāpat, ja valstī ir izveidoti tiesību normu un institūciju ietvari, kuru uzdevums ir garantēt tiesas neatkarību, efektivitāti un profesionalitāti, arī šīm normām un institūcijām jābūt efektīvām. Pretējā situācija liecina par dziedējamu demokrātijas deficitu.

Jautājums par Tieslietu padomes pastāvēšanu, tās institucionālo formu un arī par tās lēmumu efektivitāti pēc būtības ir jautājums par tiesu varas stāvokli attiecībā pret pārējām valsts varām. Savukārt šo līdzsvaru pašlaik aizvien vairāk ietekmē globalizācijas procesi un starptautisko un Eiropas organizāciju aizvien pieaugošā ietekme. İpaši šādi tiek skartas abu pārējo varu attiecības ar tiesu varu. ${ }^{2}$

Latvijas gadījumā šo efektivitāti ietekmē vairāki atšķirīgi, bet savstarpēji saistīti faktori, kurus tālāk identificēšu un analizēšu.

\section{Institucionālais risinājums}

\subsection{Vēsture}

Likums "Par tiesu varu" noteic, ka Tieslietu padome ir koleg̣iāla institūcija, kas piedalās tiesu sistēmas politikas un stratēgijas izstrādē, kā arī tiesu sistēmas darba organizācijas pilnveidošanā. ${ }^{3}$

Tieslietu padome nav ekskluzìvi Latvijai raksturīgs institucionāls fenomens, tās esamība iekḷaujas kopējā eiropeiskajā priekšstatā par to, kā optimāli pārvaldāmas un attīstāmas tiesu sistēmas.

Pirmās Tieslietu padomes mūsdienu izpratnē - neatkarīgas un autonomas institūcijas, kurām piešḳirtas būtiskas kompetences tiesu sistēmas pārvaldībā, - tika izveidotas pēc Otrā pasaules kara Francijā (1946) un Itālijā (1947). Otrajā vilnī pēc autoritāro režīmu krišanas septiṇdesmito gadu beigās Tieslietu padomes tika izveidotas Spānijā, Portugālē un Grieķijā. Savukārt trešais vilnis attiecināms uz deviņdesmito gadu vidu, kad Centrāleiropā un Austrumeiropā tika veiktas nopietnas tiesību sistēmu un valsts institūciju reformas, gatavojoties dalībai ES. Šajā periodā Tieslietu padomes tika izveidotas. Piemēram, Ungārijā un Slovēnijā, bet nedaudz vēlāk, 2002. gadā, neilgi pirms iestāšanās ES - arī Igaunijā un Lietuvā. ${ }^{4}$

\subsection{Uzbūves pazīmes}

Tieslietu padomes sastāva un kompetences starptautiskais "zelta standarts" ietver vairāku starptautiskos dokumentos atrodamu pazīmju kopumu, kuras kopsakarā veido tādu institūciju, kas spēj adekvāti iesaistīties varu līdzsvara un atsvara mehānismā un arī ES valstu starpā nodibinātajā Tieslietu padomju sadarbībā. ${ }^{5}$

\footnotetext{
${ }^{2}$ Consultative Council of European Judges (CCJE), Opinion No.18 (2015) “The position of the judiciary and its relation with the other powers of state in a modern democracy" CCJE(2015)4. Pieejams: https:// rm.coe.int/16807481al (tālāk atsaucēs - viedoklis Nr. 18), 8. punkts [aplūkots 17.03.2021.].

${ }^{3}$ Par tiesu varu: LV likums. Pieņemts 15.12.1992. [17.12.2020. red.], 89. ${ }^{1}$ pants.

${ }^{4}$ Kosař D. Perils of Judicial Self-Governments in Transitional Societies, Cambridge University Press, 2016, 122.-123. lpp.

${ }^{5}$ Pieejams: https://www.encj.eu/
} 
Šìs pazìmes ir - Tieslietu padomei tās valstī ir konstitucionāls statuss. ${ }^{6}$ Vismaz pusei Tieslietu padomes locekḷu jābūt tiesnešiem, un tiem jābūt savu kolēgu tiesnešu - ievēlētiem. Tieslietu padomei jāpiemīt ne vien padomdevēja, bet arī lēmumu pieñēmēja funkcijām, un it īpaši tai jābūt kompetentai tiesnešu karjeras jautājumos (atlase, nozīmēšana, karjeras virzība, pārcelšana, atbrīvošana, disciplinārās sankcijas). Tieslietu padomi parasti vada Augstākās tiesas priekšsēdētājs vai valsts galva. ${ }^{7}$

\subsection{Latvijas risinājums}

Analizējot Latvijas Tieslietu padomes uzbūves modeli, jāsecina, ka tas tikai daḷeji atbilst šim Eiropas standartam. Pirmkārt, Latvijas Tieslietu padomei nav konstitucionāla statusa un, lai gan tās sastāvā ir tiesnešu vairākums, tas nav vēlēts vairākums, jo divi no tiesnešiem - Augstākās tiesas priekšsēdētājs un Satversmes tiesas priekšsēdētājs - savus amatus Tieslietu padomē ieṇem ex officio. Savukārt lēmumu pieņemšanas funkcijas Tieslietu padomei ir arī tiesnešu karjeras jautāju$\operatorname{mos}^{8}$, un to, līdzīgi kā, piemēram, Spānijā, vada Augstākās tiesas priekšsēdētājs.

Šeit jāatceras, ka Tieslietu padomes veidošanas ideja Latvijā radās kā daḷa no sagatavošanās darbiem dalībai ES. Pirmsiestāšanās periodā tika izstrādāts principiāli jauns Tiesu varas likums, kas paredzēja, ka Tieslietu padome ir neatkarīga institūcija, kas pārstāv un organizatoriski vada tiesu varu. Tā izstrādā valsts politiku un stratēǵiju tiesu sistēmas attīstībā un savas kompetences ietvaros îsteno to. Savukārt Tiesu administrācijas darbojas saskaṇā ar nolikumu, ko apstiprina Tieslietu padome. Tā iecel̦ Tiesu administrācijas generāldirektoru. Tiesu administrācija nodrošina Tieslietu padomes darbu. Tiesu administrācija pilda Padomes sekretariāta funkcijas, sagatavo Tieslietu padomes lēmumu projektus, kā arī pilda citus pienākumus Tieslietu padomes uzdevumā. ${ }^{9}$ Tādẹl jāatzīst, ka pilnībā efektīva Tieslietu padome ir ne vien šodienas nepieciešamība, bet arī pagātnē neizpildìts solïjums Eiropas Savienïbas partneriem.

Par pašas Tieslietu padomes un tās darba organizāciju jāatzīmē, ka ir nepieciešams nostiprināt tās pilnvaras, sastāvu un pārvaldību, lai padome spētu būtiski ietekmēt tiesu sistēmas attīstību un kḷūt par izšķirošu dalībnieku tiesu varas politikas un stratēgijas attīstībā. Jau Eiropas Savienības līmenī konstatēts, ka Latvijas Tieslietu padomē ir viens no vissliktākajiem nodrošinājumiem Eiropas Savienībā."10

Arī Latvijā apspriestā un bieži par radikālu ideju uzskatītā Tieslietu padomes nostiprināšana Satversmē ir visai plaši izplatīta prakse Eiropas Savienībā - šādi Tieslietu padomes statuss un ilglaicība nodrošināta, piemēram, Beḷgijā, Bulgārijā, Francijā, Grieḳijā, Itālijā, Lietuvā, Maltā, Portugālē, Rumānijā, Slovākijā, Slovēnijā

6 Tieslietu padomes ir ierakstītas konstitūcijā daudzās Eiropas valstīs - kā piemērus varam minēt Beḷgiju, Bulgāriju, Horvātiju, Franciju, Griek̦iju, Itāliju, Lietuvu, Maltu, Portugāli, Rumāniju, Slovākiju, Slovēniju, Spāniju. Sk. valstu sistēmu aprakstus. Pieejams: https://www.encj.eu/members

Kosař D. 2016, 128. lpp.

${ }^{8}$ It seviški līdz ar likuma grozījumiem likumā "Par tiesu varu”, kas stājās spēkā 12.02.2018. Pieejami: https:// www.vestnesis.lv/op/2018/20.2

9 Tiesu varas likumprojekta (11.07.2002. versija autores personīgajā arhīvā) 5. un 17. nodaḷa un it īpaši 28. un 93.-95. pants.

10 Tieslietu padomes darbības stratēgija 2021.-2025. gadam, apstiprināta ar Tieslietu padomes 12.03.2021. lēmumu Nr. 16. Pieejama; http://www.at.gov.lv/lv/tieslietu-padome/dokumenti 
un Spānijā. ${ }^{11}$ Tieslietu padomi Satversmē nostiprināt tika plānots arī ar 2002. gada Tiesu varas likuma projekta paketi. ${ }^{12}$

Savukārt šodien jūtamo spiedienu attīstìt un nostiprināt Tieslietu padomi rada divas komplementāras motivācijas - pirmkārt, iekšēji generētā, kad tiesu sistēma aizvien biežāk sastopas ar nepieciešamību noformulēt savu pozīciju varu dialogā. Otrkārt, ārēji radīts spiediens, kas rodas, tiesu sistēmai aizvien vairāk apzinoties sevi kā Eiropas tiesību telpas daḷu un redzot, kādas sekas demokrātijai valstī un tās starptautiskajam prestižam nodara varu konflikts, kurā tiesu vara pakāpeniski tiek pakḷauta izpildvaras kontrolei, kā tas notiek Polijā.

Valstīs, kur izpildvarai ir būtiska loma tieslietu sistēmas pārvaldībā, jāuzdod jautājumi par tiesu sistēmas institucionālo neatkarību un arī par tiesnešu individuālo neatkarību. ${ }^{13}$ Neatkarības riski neapšaubāmi ir mazāki valstīs ar senām un stabilām demokrātijas tradīcijām, pie kurām Latvijai sevi pieskaitīt šobrīd būtu pāragri.

Analizējot status quo Latvijā, būtiski rast atbildes uz diviem savstarpēji saistītiem jautājumiem - pirmkārt, vai esošajā institucionālajā ietvarā tiesu vara spēj efektīvi formulēt un pārliecinoši argumentēt savu pozīciju dažādos tiesu sistēmas darbībai un attīstībai svarīgos jautājumos un, otrkārt, vai formulēto pozīciju respektē pārējās varas.

Tas ir būtiski, jo varām ir savstarpēji jāsadarbojas un jāpapildina citai cita, lai nodrošinātu demokrātiskā valstī nepieciešamo publisko pakalpojumu kopumu. Tādējādi pilnīga varu nošķirtība nav iespējama un to kontaktos ir pieņemams zināms "radošas spriedzes lìmenis". Lai gan visas trīs varas ir atbildīgas par atbilstošu nošķirtību to starpā, tam nav jāizslēdz cieṇas pilns dialogs, n̦emot vērā gan varas dalīšanu, gan to savstarpējo atkarību. ${ }^{14}$

Šì būtu atsevišķa sociolog̣iska pētījuma tēma, tomēr būtu a priori log̣iski pieņemt, ka tiesneša amats būtībā ir introverta un uz detaḷu analīzi vērsta profesija, kas savukārt apgrūtina aktīvu dialogu pašā tiesu sistēmas iekšienē. Tādēl vēl jo svarīgāka kḷūst konkrētu institūciju - gan tiesnešu pašpārvaldes, gan Tieslietu padomes - loma. Pārstāvju ievēlēšana šajās institūcijās ḷauj apzināt viedokḷu līderus sistēmas iekšienē, savukārt institūciju darbība garantē informācijas apriti, viedokḷu formulēšanu un standartu definēšanu un ieviešanu. Šādā kontekstā ipaši svarīgs ir arī dialogs starp Tieslietu padomi, tiesnešu pašpārvaldes institūcijām un arī tiesnešu biedrībām.

Tieslietu padomes darba kontekstā būtisks ir arī jautājums, kā tās raison d'être uztver pārējās varas, - vai tā ir, Eiropas izpratnē, tiesu sistēmas viedokli formulējoša institūcija vai, kā to, šķiet, pēdējā laikā uzsveram, izpildvara tieslietu ministra personā, konsultāciju platforma, kurā tikties un tiesu varas jautājumus apspriest trijām valsts varām. Šì pēdējā pieņēmuma gadījumā valstī nepastāv funkcionāls varu līdzsvara un atsvara mehānisms, jo tiesu varai tiek atṇemts vienīgais forums, kurā tā varētu formulēt savu autonomo viedokli visplašākajā tās darbību ietekmējošo jautājumu spektrā.

Šàda diskusija varētu šḳist ḷoti teorētiska, ja mēs jau nebūtu bijuši liecinieki sekām, kādas iestājas tieslietu sistēmas institūciju novājināšanas rezultātā. Jau pirms

\footnotetext{
11 Sk. zemsvītras piezīmi Nr. 6.

12 Sk. zemsvìtras piezīmi Nr. 9.

13 Viedoklis Nr. 18, 2. punkts.

14 Viedoklis Nr. 18, 9. un 11. punkts.
} 
dažiem gadiem toreizējā Polijas Augstākās tiesas priekšsēdētāja Malgožata Gersdorfa norādīja, ka, lai gan konstitūcija garantē tiesu neatkarību Polijā, to praksē apdraud divi faktori - pilsoniskās sabiedrības vājums un pakāpeniska institūciju noārdīšana, kā arī tas, ka sabiedrība neredz valsti kā kopējo labumu. ${ }^{15}$ Visu šo faktoru iedīgḷi diemžēl ir novērojami arī Latvijā.

\section{Sadarbỉbas kultūra un izpratne par kopigo misiju}

Kā jau norādīts iepriekšējā sadaḷā, valsts varas nevar būt pilnīgi neatkarīgas cita no citas un tām jāsadarbojas valsts un sabiedrības labklājības vārdā. Arī Tieslietu padomes mērḳu īstenošanai ir būtiska optimāla sadarbība ar izpildvaru un likumdevēju. Šìs sadarbības priekšnoteikumi savukārt ir vienota mērḳu izpratne, kā arī savstarpēja uzticēšanās, kas balstās uz normām, procedūrām, sadarbības kultūru un pieredzi. Savukārt vienas varas izteiktai kritikai par otru jābalstās savstarpējā cieñā. ${ }^{16}$

Vienotus mērķus Tieslietu padome nosaka savā stratēgijā, bet šo mērḳu optimālu realizāciju veicina skaidrs materiālo un procesuālo normu ietvars, kas regulē gan tiesu varu kopumā, gan pašas Tieslietu padomes kompetenci.

Savukārt dažkārt vērojamā likumdevēja vēlme dot pārspīlēti detalizētu regulējumu var liecināt par neuzticību valsts varu starpā. Jautājums par to, kad un cik bieži grozāmi likumi, ir likumdevēja kompetencē, bet vajadzētu izvairīties no pārāk biežiem grozijjumiem likumos, kas regulē tiesu sistēmas funkcionēšanu. ${ }^{17}$

Šeit jāatzīmē, ka Latvijas tiesību sistēmu raksturojošie normu plūdi nav gājuši secen arī tiesu sistēmu regulējošajām normām. Tā likums "Par tiesu varu" kopš tā pieṇemšanas ir ticis grozīts 44 reizes, savukārt tā apjoms ir gandrīz trīskāršojies. ${ }^{18}$

Tiesību sistēmas attīrīšana no sīkumaina tiesiskā regulējuma ir iespējama tikai kopsakarā ar tiesību piemērotāja lomas palielināšanu un, šeit jāuzsver, arī ar valsts varu savstarpējās uzticības pieaugumu. ${ }^{19}$

Arī Egils Levits ir daudzkārt norādījis, ka būtiski panākt to, lai tiesību piemērotājs - ierēdnis vai tiesnesis - spēj abstrakti formulētus tiesiskas valsts principus pārvērst konkrētā, tiem atbilstošā rīcībā. ${ }^{20}$

Potenciāli valsts varu sadarbības efektivitāti ilustrē arī situācijas, kad Tieslietu padome, analizējot kādu problēmu pēc būtības, konstatē, ka tās cēloṇi daḷeji rodami arī jomās, kuru regulējums sniedzas ārpus tiesu varas, Tieslietu padomes un arī Tieslietu ministrijas kompetences, un tās lēmumu izpildei nepieciešama

15 Borkowski G., red. The limits of Judicial independence? Varšava 2016, 233.-236. lpp.

16 Viedoklis Nr. 18, 53. punkts.

17 Viedoklis Nr. 18, 45. punkts.

18 Stupins A. Legísprudence kā zāles pret normofỉiju. Jurista Vārds, 2020, Nr. 46, 17.-19. lpp.

19 Ola Wiklund savā rakstā Taking the World View of European Judge Seriously-some reflections on the role of ideology in adjudication grāmatā Judicial discretion in European Perspective, Kluwer Law international (2003, 29. lpp.,) uzsver, ka tiesnesim ir pastāvīgi jāizdara izvēles starp konfliktējošām politikām (policy). Vienlaicīgi tiesneši uzstāj gan attiecībā uz tiesību un politikas nošķiršanu, gan diskursīvo konvenciju, ka viņu ideologiiskie uzskati, kas attīstīti juridiskā argumentācijā, nav ideologíiski. Vērojot diskusijas Saeimā un sabiedrībā pēc Satversmes tiesas 12.11.2020. sprieduma Nr. 20193301 "Par Darba likuma 155. panta pirmās daḷas atbilstību Latvijas Republikas Satversmes 110. panta pirmajam teikumam”, jāsecina, ka diskusijas par šo tēmu ir aktuālas arī Latvijā, tomēr tās būtu vēlams ievirzīt akadēmiskākā un cieņpilnākā gultnē.

${ }^{20}$ Levits E. Dažas tēzes par Latvijas tiesību sistēmas problēmām. Grām.: Valstsgriba. Idejas un domas Latvijai 1985-2018. Rīga: Latvijas Vēstnesis, 2019, 361. lpp. 
Saeimas, Ministru kabineta un atsevišķu ministriju efektīva iesaiste. Šāda situācija izveidojās, piemēram, Tieslietu padomes darba grupai analizējot ilgstošo tiesvedību cēloṇus ${ }^{21}$. Jautājuma analīzi sākotnēji iniciēja Valsts prezidents savā runā 2019. gada tiesnešu konferencē, savukārt, izskatot tai iesniegto ziņojumu, Tieslietu padome vērsās ar lūgumu risināt atsevišķus jautājumus ne vien pie Tieslietu un Iekšlietu ministrijām, bet arī pie Labklājības un Veselības ministrijām un pat Valsts bērnu tiesību aizsardzības inspekcijas. Tāpat šis ziṇojums tika izskatīts premjera vadītajā Noziedzības novēršanas padomē.

Atsevišķa pētījuma vērta būtu Satversmes tiesas loma tiesu varas sistēmisko jautājumu risināšanā. Šeit īpaši jāpiemin, ka atsevišķos gadijumos, tiesu varai nerodot kompromisu ar izpildvaru un likumdevēja varu, Tieslietu padome var būt spiesta vērsties Satversmes tiesā, šādas tiesības tai savas kompetences jomā piešķir likuma "Par tiesu varu" 89. ${ }^{11}$ panta trešā daḷa. Savukārt, Satversmes tiesai pasludinot spriedumu, aktuāls kḷūs tās spriedumu izpildes jautājums, kas visbiežāk jānodrošina izpildvarai un likumdevējam. Būtiski, lai šì izpilde tiktu veikta pēc būtības, nevis formāli, kas var novest pie atkārtotas tiesvedības, kā, piemēram, tiesnešu algu jautājumā, kur pēdējā spriedumā ${ }^{22}$ gan pieteikuma iesniedzējam, gan Satversmes tiesai nācās savā argumentācijā atkārtot jau iepriekš konstatēto.

\section{Ekonomisko lietu tiesas izveides piemērs}

Jaunizveidotās Ekonomisko lietu tiesas (turpmāk - ELT) tapšanas gaitu pavadīja pastāvīgas diskusijas pamatā tiesu un izpildvaras starpā gan par šīs tiesas lietderību, gan par tās veidošanā izvēlēto risinājumu efektivitāti. Tieslietu padomes vairākums jau sākotnēji uzsvēra, ka iepriekšējos gados tiesu sistēmā tika veiktas trīs apjomīgas reformas - tika pabeigta pāreja uz tīro trīs instanču tiesu sistēmu (tiesu palātu likvidācija Augstākajā tiesā un piekritības korekcijas instanču starpā), zemesgrāmatu tiesneši tika integrēti vispārējās jurisdikcijas tiesās, kā arī trešā, šajā kontekstā vissvarīgākā - tiesu teritoriālā reforma, apvienojot rajona (pilsētas) tiesas. Šìs pēdējās reformas mērḳis bija izveidot lielākas tiesas un tādējādi radīt priekšnoteikumus tiesnešu padziḷinātai specializācijai apvienojumā ar reālas iespējas radī̌̌nu lietu nejaušai sadalei.

Laikā, kad tika publiskota ideja par ELT izveidi, šo reformu rezultāti vēl nebija apkopoti un izsvērti. Savukārt tās nepieciešamības pamatojums ne vien nebija saistīts ar minēto reformu rezultātiem, bet arī nonāca ar tiem pretrunā, it īpaši ar vairākus iepriekšèjos gadus realizētās tiesu teritoriālās reformas mērḳi radīt priekšnoteikumus padziḷinātai vispārējo tiesu tiesnešu specializācijai, nevis specializētu tiesu veidošanu. Savukārt kontinuitātes trūkums tieslietu sistēmas attīstības plānošanā neveicina tās stabilitāti un pilnveidošanos.

Tāpat tika uzsvērts īpaši no konstitucionālo tiesību viedokḷa būtiskais aspekts par visu sabiedrības locekḷu vienlīdzīgām tiesībām uz piekḷuvi (kvalitatīvai) tiesai. ELT izveidošana tika pamatota ar ekonomiskā izdevīguma un investoru motivācijas loǵiku, savukārt Tieslietu padome uzsvēra, ka Latvijai kā sociāli atbildīgai

${ }^{21}$ Ziņojums par Tieslietu padomes 10.02.2020. lēmuma Nr. 11 izpildi. Pieejams: http://www.at.gov.lv/lv/ tieslietu-padome/petijumi-apkopojumi-prezentacijas [aplūkots 17.03.2021.].

22 Satversmes tiesas 26.10.2017. spriedums lietā Nr. 2016-31-01. Pieejams: https://www.satv.tiesa.gov.lv/web/ viewer.html?file=/wp-content/uploads/2017/10/2016-31-01_Spriedums.pdf\#search= 
valstij jānodrošina profesionāla, efektīva tiesu sistēma, kvalitatīvi nolēmumi un tiesu prakses vienādošana ne vien kādā ipaši izceltā lietu kategorijā, bet visos jautājumos. $^{23}$

Tieslietu padomes balsis ELT atbalstī̌sanas jautājumā sadalījās deviṇi "pret” un divi "par". ${ }^{24}$

Tomēr šis tiesu sistēmu uzbūvei un attīstìbai ḷoti būtiskais jautājums nebija tas, kura kontekstā Tieslietu padomes viedoklī ieklausijās izpildvara ${ }^{25}$ un likumdevējs.

Tiesu veidojot, tika izvēlēti vairāki interesanti juridiski ceḷi - ar grozījumiem likuma "Par tiesu varu" pārejas noteikumos uz ELT tika pārceltas 10 štata vietas, lai gan vispārējā šì paša likuma norma, kas šajā gadījumā būtu 32. panta trešā daļa, noteic, ka tiesnešu kopskaitu rajonu (pilsētu) tiesās un ELT, kā arī Administratīvajā rajona tiesā nosaka Saeima pēc Tieslietu padomes priekšlikuma. Tiesnešu skaitu katrā tiesā nosaka Tieslietu padome pēc tieslietu ministra priekšlikuma. Tāpat pārejas noteikumos tika noteikts, ka Tiesu administrācija nodrošina ELT tiesneša amata kandidātu mācības, un visbeidzot ELT izveidošanas steigā ar likuma "Par tiesu varu" pārejas noteikumiem tika grozìtas arī citos likumos, tai skaitā kriminālprocesā, noteiktās piekritības normas.

Neatkarīgi no tā, vai šo juridisko risinājumu izvēli noteica neuzticība Tieslietu padomei, kas bija iestājusies pret nepieciešamību veidot ELT, vai steiga, vai abu faktoru kopums, ELT izveides juridiskie risinājumi ne pēc formas, ne saturiski nebija ideāli. Tomēr tagad, kad šì tiesa ir izveidota, katrai no varām jāizdara viss tās kompetencē esošais un iespējamais, lai nodrošinātu veiksmīgu jaunās tiesas darbību.

\section{Nepieciešamība noskaidrot lēmumu vietu normatīvo aktu sistēmā}

2018. gadā, veicot plašus Tieslietu padomes kompetenci skarošus grozījumus likumā "Par tiesu varu", Saeima nodeva divus iepriekš Ministru kabineta kompetencē esošus jautājumus - jauno tiesnešu atlases procesu un tiesu teritoriju un atrašanās vietu - Tieslietu padomes pārziñā. ${ }^{26}$ Tātad būtībā Tieslietu padomei tika ar likumu uzlikts pienākums izdot normatīvus aktus par plašu personu loku, kas nav tai institucionāli padotas, tomēr palika neatbildēts tiesību teorijas jautājums, vai šo pilnvaru realizācijas rezultātā pieṇemtie normatīvie akti ir uzskatāmi par ārējiem normatīviem aktiem. ${ }^{27}$ Atbildei uz šo jautājumam ir arī praktisks svars tādā nozīmē, ka, apšaubot Tieslietu padomes lēmuma "svaru" tiesību sistēmā, rodas šaubas arī par to, vai tā realizācijai iespējams piesaistìt finanšu līdzekḷus. ${ }^{28}$

${ }^{23}$ Tieslietu padomes priekšsēdētāja 06.06.2019. vēstule Nr. 13-3/687 Ministru prezidentam (nos. kopija autores personīgajā arhīvā).

24 03.06.2019. sēde (protokols autores personīgajā arhīvā).

${ }^{25}$ Ministru kabinets apstiprināja konceptuālo ziņojumu "Par ekonomisko lietu tiesas izveidi" ar savu 22.08.2019. rikojumu Nr. 407 (prot. Nr. 35, 17. §). Pieejams: https://likumi.lv/ta/id/308908-par-konceptualo-zinojumu-par-ekonomisko-lietu-tiesas-izveidi [aplūkots 17.03.2021.].

26 Attiecīgi likuma "Par tiesu varu" 51. panta 3. daḷa un 29. panta 3. dal̦a, 35. panta 2. daḷa.

${ }^{27}$ Izvērsumu sk:. Šulmane D. Par Tieslietu padomes izdotajiem normatīvajiem aktiem. Latvijas Republikas "Augstākās Tiesas Biḷetens", 2020, Nr. 21, 62. lpp.

${ }^{28}$ Piemēram, Ekonomisko lietu tiesas veidošanas kontekstā radās jautājums - ja Tieslietu padomes izstrādātajā atlases kārtỉbā ir iekḷauta kandidātu apmācība, vai Tiesu administrācija uz šì Tieslietu padomes lēmuma pamata ir tiesīga pārdalīt līdzekḷus apmācības nodrošināšanai (no intervijas ar Tiesu administrācijas direktoru; autores personīgajā arhìvā). Pastāvot šaubām par Valsts kontroles viedokli šajā jautājumā, pēc Tieslietu ministrijas priekšlikuma šis pienākums Tiesu administrācijai tika uzlikts ar likuma "Par tiesu varu" pārejas noteikumiem. 
Akadēmiskajā diskursā par normatīvo aktu kvalifikāciju kā “ārēju” šķietami saduras divas pieejas - vērtējot pēc normatīvā akta adresāta vai vērtējot pèc leǵitimācijas ķēdes.

Vērtējot divus minētos gadījumus pēc adresāta kritērija, ir skaidrs, ka to tvērums pārsniedz pašas tiesu sistēmas robežas, būtībā divos dažādos aspektos regulējot piekḷuvi tai. Pirmajā gadījumā piekḷuve profesijai nozīmē - kā likuma prasībām atbilstoša persona var kḷūt par tiesnesi. Otrajā gadījumā, nosakot tiesu teritoriju sadalījumu un to atrašanās vietas, Tieslietu padome regulē teritoriālās piekritības un piekḷuves tiesai jautājumus - šis regulējums būtībā skar ikkatru personu, kas potenciāli varētu tiesāties Latvijā. No šāda viedokḷa būtu grūti apšaubìt, ka Tieslietu padome izdod ārējus normatīvus aktus.

Skatoties leg̣itimācijas ķēdes aspektā, pirmkārt, vajadzētu atzīmēt, ka tiesu varai kopumā leǵitimitātes avots ir valsts konstitucionālais ietvars, savukārt individuālu tiesnešu gadījumā - likumīgā iecelšanas procedūra un darbība strikti likuma ietvarā. ${ }^{29}$

Tieslietu padomes sastāvā Saeimu un, iespējams, arī valdību ${ }^{30}$ ex officio pārstāv ievēlēts politiķis. Visi tiesneši ir Saeimas amatā iecelti un Tieslietu padomē nonākuši savu kolēğu vēlēti - gan tiesnešu konferencē ievēlētie pirmās instances un apelācijas instances pārstāvji, gan Augstākās tiesas plēnumā ievēlētais Augstākās tiesas pārstāvis. Arī ex officio tieslietu sistēmu pārstāvošie Satversmes tiesas priekšsēdētājs un Augstākās tiesas priekšsēdētājs savos tiesu amatos ir savu kolēgu ievēlēti. Tāpat savos amatos ir ievēlēti brīvo juridisko profesiju pārstāvji, kas kā attiecīgo biedrību vadītāji arì ir likuma (lasi - Saeimas) nozìmēti Tieslietu padomes ex officio locekḷi. Katrs Tieslietu padomes loceklis tās sastāvā ir nonācis precīzi tādā veidā, kā to dažādos avotos ir noteicis likumdevējs.

Turklāt būtu jāṇem vērā arī lietderības apsvērums - nevar veidoties situācija, kurā, likumdevējam izškiroties par kādas jomas regulējuma pārdelegēěšnu no izpildvaras tiesu kompetencē, attiecīgā regulējuma normu statuss pazeminās un tātad samazinās to efektivitāte. Ja valsts likumdevēja personā uzliek par pienākumu noregulēt kādu jautājumu, šo regulējumu darot vispārzināmu ar oficiālas publikācijas starpniecỉbu, būtu tikai log̣iski, ja Tieslietu padomes attiecīgais lēmums tās kompetences jomā tiesību sistēmā ien̦emtu tādu pašu vietu kā Ministru kabineta noteikumi.

\section{Kopsavilkums un secinājumi}

1. Likumā definētā Tieslietu padomes loma un sastāvs tikai daḷēji atbilst Tieslietu padomju Eiropas modelim. Būtu nopietni apsverama arī Tieslietu padomes stratēgijā 2021.-2025. gadam ietvertā Tieslietu padomes nostiprināšana Satversmē, kā arī tās personālsastāva korekcija, lai Tieslietu padome spētu veikt tai sākotnēji iecerēto lomu - būt par tiesu varas balsi varas līdzsvara un atsvara mehānismā.

\footnotetext{
29 Viedoklis Nr. 18, 13.-18. punkts.

${ }^{30}$ Tieslietu ministrs teorētiski var būt gan Saeimā ievēlēts, gan neievēlēts politiḳis vai pat politiski neangažēts tiesību jomas profesionālis.
} 
2. Tieslietu padomes dažāda tipa kompetencēm ir atškirīga efektivitātes pakāpe kamēr konkrēti lēmumi (piemēram, tiesnešu karjeras jautājumos) tiek pieṇemti un īstenoti bez aizķeršanās, Tieslietu padomes nostāja plašākos tiesu sistēmas politikas jautājumos mēdz palikt izpildvaras un likumdevēja nesadzirdētas.

3. Tiesnešu kā etosa pašdefinēšanās un Tieslietu padomes darbs ir savstarpēji ietekmējoši efektivitātes faktori.

4. Līdz ar Tieslietu padomes izveidošanu un it sevišķi līdz ar kompetenču piešķiršanu tai noteikt jauno tiesnešu atlases kārtību un tiesu darbỉbas teritorijas un to atrašanās vietas, nepieciešams izveidot vienotu izpratni par Tieslietu padomes lēmumu statusu normatīvo aktu sistēmā. Tieslietu padomes lēmumiem jābūt efektīvāk sasaistītiem ar budžeta procesu, pretējā gadījumā arī atsevišķas tai piešķirtās kompetences var ilgtermiṇā izrādīties iluzoras. 